\title{
Teologia de fronteira: aportes do método da correlação de Paul Tillich
}

\author{
Carlos Alberto Motta Cunha*
}

\section{RESUMO}

No pensamento de Paul Tillich, a "fronteira" é chave hermenêutica de sua vida e teologia, a saber, a reivindicação do espaço fronteiriço entre diferentes saberes e possibilidades. Tillich desenvolveu o método da correlação, segundo o qual o conteúdo da Revelação cristã se apresenta e demonstra como resposta às perguntas cruciais que brotam da existência do ser humano na modernidade. Resistindo a teologias que levam em conta apenas o querigma, sem olhar o destinatário, Tillich apresenta a teologia apologética, ou seja, uma "teologia que-dá-respostas" aos anseios existenciais do ser humano. No projeto tillichiano, a situação existencial do sujeito determina a exposição do conteúdo da Revelação divina sem que para isso relativize as Boas Novas da salvação. Sem esta situação, não há condições de perguntas certas em busca de boas respostas. Tillich fez desta dinâmica o eixo do método da correlação, devidamente utilizado não só na sua vida, mas também na sua grande obra, a Teologia Sistemática. Palavras-chave: Lugar de fronteira. Teologia de fronteira. Paul Tillich. Método da correlação. Epistemologia.

\section{BORDER THEOLOGY: THE CONTRIBUTIONS OF TILLICH'S METHOD OF CORRELATION}

\begin{abstract}
For Paul Tillich, the "border" is the hermeneutic key by which to understand his life as well as his theology, that is, the claim for a bordering space between different knowledges and possibilities. Tillich developed his method of correlation on the premises that, in modernity, the content
\end{abstract}

Bolsista do Programa Nacional de Pós-Doutorado - CAPES e Faculdade Jesuíta de Filosofia e Teologia (FAJE). E-mail para contato: carlosamc04@gmail.com. Currículo Lattes: http://lattes.cnpq.br/6296606573263223. 
of Christian Revelation presents and shows itself as an answer to the crucial questions that emerge from human existence. The author, who was resistant to theologies that only consider the kerygma without taking into account the receiver, proposed an apologetic theology, an "answering theology" for the existential questions of humankind. In Tillich's project, the existential situation of the subject determines the exposition of the content of divine Revelation without relativizing the Good News of Salvation. This condition is necessary to find the right questions leading to the correct answers. Tillich used this dynamics as the core of his method of correlation, applying it to his life as well as to his masterpiece, Systematic Theology.

Keywords: Bordering space, Border Theology. Paul Tillich. Method of correlation. Epistemology.

\section{TEOLOGÍA DE FRONTERA: CONTRIBUCIONES DEL MÉTODO DE LA CORRELACIÓN DE PAUL TILLICH}

\section{Resumen}

En el pensamiento de Paul Tillich, la "frontera" es la clave hermenéutica de su vida y teología, a saber, la reivindicación del espacio fronterizo entre diferentes saberes y posibilidades. Tillich desarrolló el método de la correlación, según el cual el contenido de la Revelación cristiana se presenta y demuestra como respuesta a las preguntas cruciales que brotan de la existencia del ser humano en la modernidad. Resistiendo a teologías que sólo consideran el kerigma, sin mirar el destinatario, Tillich presenta la teología apologética, o sea, una "teología que-da-respuestas" a los anhelos existenciales del ser humano. En el proyecto tillichiano, la situación existencial del sujeto determina la exposición del contenido de la Revelación divina sin que para eso relativice las Buenas Nuevas de la salvación. Sin esta situación, no hay condiciones para preguntas ciertas en busca de buenas respuestas. Tillich hizo de esta dinámica el eje del método de la correlación, debidamente utilizado no sólo en su vida, sino también en su gran obra, la Teología Sistemática.

Palabras-clave: Lugar de frontera. Teología de frontera. Paul Tillich. Método de la correlación. Epistemología. 


\section{Introdução}

A história da teologia cristã é marcada por teólogos que ousaram pensar e fazer teologia de fronteira, isto é, habitaram espaços limítrofes como lugares ideais para a reflexão da fé cristã diante dos desafios das sociedades circundantes. Grandes teólogos do século XX, como Karl Barth (1886-1968) e sua teologia dialética, Rudolf Bultmann (18841976) e sua teologia existencial, o cristianismo a-religioso de Dietrich Bonhoeffer (1906-1945), a controvérsia modernista e apologética de Alfred Loisy (1857-1940) e Maurice Blondel (1861-1949), Karl Rahner (1904-1984) e a teologia transcendental, a teologia da libertação de Gustavo Gutierréz e a libertação da teologia de Juan Luis Segundo, assim como tantos outros teólogos e teólogas, de várias tradições cristãs, são exemplos de labores teológicos engajados.

$\mathrm{Na}$ lista dos grandes teólogos de fronteira não pode faltar o teólogo germano-americano Paul Tillich, conhecido como o "teólogo da fronteira". A sua vida e a sua teologia se deram numa situação de fronteira (boundary-situation) como o espaço ideal para encontros e diálogos entre os saberes. A teologia tillichiana é marcada por correlações próprias de quem habita espaços fronteiriços. Sua contribuição epistemológica, conhecida como método da correlação, consiste em estabelecer uma ponte razoável e autêntica entre a fé, a Revelação cristã e a cultura moderna. Para este fim, ele desenvolveu o seu caminho metodológico, segundo o qual o conteúdo da Revelação cristã se apresenta e demonstra como "resposta" às perguntas cruciais que brotam da existência do ser humano na modernidade.

O método de Tillich, que tem como lócus a situação de fronteira, perpassa toda a sua vida e a sua teologia e pretende explicar os conteúdos da fé por meio de questionamentos existenciais que interpelam a intelecção da fé. Mais do que um jogo de perguntas e respostas, a correlação se dá na experimentação da realidade. Só há possibilidade de fronteira na abertura provocada pela situação. O próprio termo "correlação" já comporta em si mais de uma possibilidade, ocupando, assim, um lugar de prestígio na comunicação acadêmica, eclesial e social, pois abre caminho para expressar a relação entre conceitos, ideias e pensamentos que podem ser totalmente diferentes. 


\section{A revelância do pensamento de Paul Tillich}

O húmus da fronteira ${ }^{1}$ no pensamento tillichiano é mais do que estar na linha fronteiriça entre dois continentes, mas, ao mesmo tempo, estar numa posição entre mundos, entre os tempos, em movimento constante em busca de diálogos que favoreçam e enriqueçam o mundo e o humano. Pensa-se não em monólogos, mas em encontros capazes de produzir interações entre os sujeitos e a ampliação de horizontes. Tillich também pode ser considerado como o "filósofo da fronteira", pois sua leitura da teologia vai ser preponderantemente uma leitura filosófica. A filosofia e a teologia são duas áreas em constante diálogo no seu pensamento. Numa entrevista concedida a Werner Rode, no Union Theological Seminary, ele disse que "sempre esteve na fronteira entre o filosófico e o teológico". A fronteira entre a racionalidade filosófica e a dimensão fiduciária da teologia é chave hermenêutica de sua vida e teologia, a saber, a reivindicação do espaço entre diferentes saberes e possibilidades.

Estar na fronteira consiste em estar numa posição frutífera para o pensamento com horizontes amplos. Tillich não escreveu só sobre teologia e filosofia. A riqueza de seu pensamento engloba assuntos diversos: ética, história do pensamento cristão, socialismo, ontologia, psicologia, arte, ciência, religião e mais alguns assuntos. Sua obra toda é de profundo impacto e de grande versatilidade. Impressiona a dinamicidade e a capacidade de abertura do seu pensamento. Suas reflexões filosófico-teológicas possibilitam convergências entre várias áreas do saber. Mesmo com toda esta abertura dialógica, o pensamento de Tillich é cortado por um tema transversal: a dimensão religiosa de toda cultura, revelada pelas instâncias da vida no decorrer da história. Ele mesmo deixa transparecer a essência da sua teologia da cultura ao afirmar que:

\footnotetext{
Observamos que nos escritos de Paul Tillich a palavra utilizada por ele para "fronteira" é "boundary" e não "frontier". As duas palavras podem ser utilizadas para indicar limites de áreas. No entanto, a palavra "boundary", no sentido figurado, aponta para a possiblidade de flexibilização de recuo e avanço das fronteiras do conhecimento. Portanto, ela parece ser mais rica de significado do que a palavra "frontier". Cf. a explicação do verbete "boundary", in: CROWTHER, Jonathan (Ed.). Oxford Advanced Learner's Dictionary. 50.ed. Oxford University Press, 1998. p.129.

2 Cf. A Conversation with Dr. Paul Tillich. Disponível em: < https://www.youtube.com/ watch?v=JRoyr-y01Lg\#t=152>. Acesso em 2 de set. 2014.
} 
Apesar de durante a maior parte de minha vida adulta eu ter sido professor de Teologia Sistemática, o problema da relação entre religião e cultura sempre esteve no centro de meus interesses. A maioria de meus escritos tenta definir a maneira como o cristianismo se relaciona com a cultura secular (TILLICH, 2009, p.33).

O pensamento de Tillich é explorado sistematicamente em dezenas de instituições de pesquisa ao redor do mundo. São muitos os artigos, ensaios, monografias, dissertações e teses envolvendo sua obra. O site da Deutsche Paul Tillich Gesellschaft ${ }^{3}$, por exemplo, mostra os dados de mais quatro sociedades científicas entre as quais a Sociedade Paul Tillich do Brasil ${ }^{4}$ e centros de pesquisa dedicados ao estudo do seu pensamento.

No Brasil, além da Sociedade Paul Tillich do Brasil, há dois núcleos de pesquisa dedicados ao estudo de suas obras: um coordenado por Etienne Higuet, no departamento de Pós-Graduação em Ciências da Religião da Universidade Metodista de São Paulo (UMESP) e, outro, coordenado por Enio Mueller, no Grupo de Pesquisa de Teologia e Inter/Transdisciplinaridade, do Instituto Ecumênico de Pós-Gradução da Escola Superior de Teologia (EST).

Mueller chama a atenção para a relevância da pesquisa científica do pensamento tillichiano quando cita as produções feitas ao redor do mundo por instituições de destaque:

Encontros internacionais de pesquisadores são regularmente promovidos pelas sociedades P.T. alemã (anual), americana (anual) e francesa (bianual). Além disso, um grande congresso internacional se realiza em Frankfurt a cada dois anos. Os anais destes eventos, quase sempre disponíveis em forma de publicação impressa, representam um significativo aporte à pesquisa [...] Desde 1999, a LIT Verlag (Münster, Hamburgo, Londres) publica uma série de Tillich-Studien (monografias maiores) e Abteilung Beihefte (textos e papers menores). Estas séries, especialmente a maior, incluem um seleto número de teses e dissertações produzidas anualmente por pesquisadores/as em todos os cantos do planeta (MUELLER, BEIMS, 2005, p.38-39).

3 Cf. O site de pesquisa alemã sobre o pensamento de Paul Tillich. Disponível em: $<$ www. uni-trier.de/uni/theo/tillich.html>. Acesso em 2 de set. 2014.

4 Cf. O site da Sociedade. Disponível em: <www.angelfire.com/sc/paultillich/>. Acesso em 2 de set. 2014. 
O periódico científico Correlatio, revista da Sociedade Paul Tillich do Brasil e do Grupo de Pesquisa Paul Tillich, da Universidade Metodista de São Paulo (UMESP), publica semestralmente trabalhos de pesquisadores que relacionam o pensamento tillichiano com áreas como economia, política, psicanálise, educação, religião, arte, linguagem etc., além de temas relacionados à teologia e à filosofia. ${ }^{5}$

Relevante, também, é a produção feita no âmbito da Associação Paul Tillich do Brasil. Fundada em 1994, a instituição está entre as várias instituições de pesquisa ao redor do mundo dedicadas ao estudo em diálogo com a produção de Tillich ${ }^{6}$. São pesquisas variadas em múltiplos diálogos, tanto com a teologia tillichiana, no seu conjunto, quanto com os métodos propostos por ele. A Associação atrai, além de pesquisadores, ministros ligados a várias igrejas, estudantes e público em geral, com o objetivo de difundir e estimular o pensamento tillichiano.

As ideias de Paul Tillich são marcadas por grande complexidade e aberturas diversificadas. A relação entre religião e cultura secular proposta por ele continua inspirando estudiosos, filósofos, teólogos e cientistas da religião da contemporaneidade em busca de pensamentos, filosofias e teologias relevantes às sociedades hodiernas. Etienne A. Higuet sintetiza a riqueza do pensamento de Tillich:

Até hoje não consigo explicar plenamente a razão deste fascínio, quando vejo o grau de abstração alcançado por muitos textos de Tillich. Só sei que Tillich toca algum ponto nodal de todos aqueles que não se satisfazem mais com a rotina eclesiástica ou teológica em que vivem. Pessoalmente, tive o sentimento, desde o primeiro momento - na época do Concílio Vaticano II - de que Tillich colocava as verdadeiras questões, em meio a uma crise de civilização que se aprofundava cada vez mais. Ele trazia a descoberta da profundidade religiosa em toda experiência existencial, uma fé não dogmática, uma espiritualidade ecumênica e inter-religiosa, a coragem de ser e de assumir a ambiguidade, a alienação, a dúvida, o sem-sentido, a participação em todos os grandes movimentos sociais,

5 Cf. Estudos que tratam sobre a dinamicidade das convergências entre o pensamento de Paul Tillich e as várias áreas do saber. Disponível em: $<$ https://www.metodista.br/revistas/ revistas-ims/index.php/COR/index $>$. Acesso em 2 de set. 2014.

6 Cito como exemplo The North American Paul Tillich Society, sociedade nos Estados Unidos em parceria com sociedades na Alemanha e França empenhadas em estudar o pensamento de Paul Tillich. Cf. O site da sociedade. Disponível em: $<$ http://www.napts. org/pages/about.html>. Acesso em 8 de set. 2014. 
políticos e culturais do nosso tempo. Isso, apesar do inevitável 'provincianismo' do nosso teólogo (HIGUET apud CALVANI, 2010, p.8).

Discussões teológicas atuais como a Teologia do Diálogo Inter-religioso e a Teologia Pública recorrem constantemente ao pensamento de Paul Tillich. Estas teologias encontram nele e, principalmente, no método da correlação, embasamento teórico. Na Teologia do Diálogo Inter-religioso, por exemplo, Claude Geffré, em Crer e interpretar: a virada hermenêutica da teologia, dialoga com o pensamento de Tillich com o objetivo de mostrar a universalidade do símbolo da cruz ligada ao sacrifício de uma particularidade sintetizada na fórmula tillichiana: “Cristo é Jesus e a negação de Jesus" (GEFFRÉ, 2004, p.167). Já Roger Haight, interessado também na Teologia do Diálogo Inter-religioso, ao explicitar o seu método cristológico, chama-o de método hermenêutico de correlação crítica que almeja "ser fiel ao testemunho do passado e interpretá-lo de maneira tal que seja significativo para a consciência contemporânea" (HAIGHT, 2004, p.151).

No âmbito da Teologia Pública, David Tracy, o teólogo do discurso público (publicness) também dialoga com o pensamento de Tillich. No livro Imaginação Analógica, ele assume o método da correlação como exemplo da necessidade contemporânea de encontrar correlações mutuamente críticas entre interpretações teologicamente cunhadas tanto da situação como da mensagem, a necessidade de tentar ser fiel tanto à manifestação religiosa como à proclamação (TRACY, 2004, p.534). Jürgen Moltmann, também pensando na Teologia Pública, vê a teologia cristã como pública por causa do Reino de Deus em um fazer sempre de forma correlativa. Ela deve ser, ao mesmo tempo, conforme a Escritura e contextual. Ela torna-se uma teologia pública, que compartilha os sofrimentos desta época e que formula suas esperanças em Deus no lugar em que vivem os seus contemporâneos (MOLTMANN, 2004, p.75).

Os exemplos citados acima demonstram a relevância do pensamento de Paul Tillich para a Teologia, a Filosofia, as Ciências da Religião e para outras áreas do conhecimento. No âmbito teológico, como o pensamento tillichiano, a partir do espaço de fronteira, foi elaborando dando origem a uma intelecção da fé cristã contextual? 


\section{Teologia de fronteira}

Somente nas duas últimas décadas de sua existência octogenária é que Tillich conseguiu ocupar um lugar de proeminência no firmamento da teologia. Isso ocorreu também pelo fato de que todas as suas maiores obras foram publicadas nos últimos anos de sua vida. Essa informação é significativa se considerarmos a vida de Tillich e os momentos de mudança de pensamento que geraram nele um espírito mais maduro, crítico e consciente.

Tillich coloca-se na fronteira entre o protestantismo liberal e a neo-ortodoxia barthiana. Para Stanley Grenz e Roger Olson, ele faz parte do grupo de teólogos chamados estranhamente de "liberais corrigidos" (GRENZ, OLSON, 2003, p.136.). Num primeiro momento, Tillich fez parte do movimento da teologia dialética de Karl Barth com o propósito de combater o liberalismo teológico e os seus efeitos sobre o cristianismo. Desde então, se opôs ao racionalismo de Adolf Harnack para, num segundo momento, se opor também à pura fé de Barth e à sua teologia querigmática. Para isto, Tillich baseou sua teologia no princípio da correlação, que é o método fundamental que perpassa toda a sua teologia.

Como dissemos, o propósito teológico de Tillich consiste em estabelecer uma ponte razoável e autêntica entre a fé, a Revelação cristã e a cultura moderna. Em suas palavras:

Um sistema teológico deve satisfazer duas necessidades básicas: a afirmação da verdade da mensagem cristã e a interpretação desta verdade para cada nova geração. A teologia oscila entre dois polos: a verdade eterna de seu fundamento e a situação temporal em que esta verdade eterna deve ser recebida. Não são muitos os sistemas teológicos que souberam combinar perfeitamente essas duas exigências. A maioria deles ou sacrificam elementos da verdade ou não são capazes de falar no momento atual (TILLICH, 2005, p.22).

A crítica que Tillich fez à teologia querigmática de Barth é devida ao fato de que ela levava mais em conta o anúncio, o querigma, sem dar o devido valor o outro polo, o destinatário, representado por todas as várias formas culturais que exprimem a interpretação da existência por parte do ser humano moderno. Daqui nasce o projeto tillichiano de 
completar a "teologia querigmática" com uma "teologia apologética", ou seja, uma "teologia que-dá-repostas" (answering theology).

A teologia apologética tillichiana ou a "teologia que-dá-repostas" busca formular e comunicar os seus conceitos de modo que fale verdadeiramente à situação moderna. Por "situação", Tillich referia-se às "questões e preocupações particulares das pessoas dentro de nossa cultura, o aspecto científico e artístico, as formas econômicas, políticas e éticas através das quais elas expressam sua interpretação da existência"(GRENZ, OLSON, 2003, p.139.). Não é sem motivos que ele criticava duramente o fundamentalismo teológico e a teologia querigmática, que não se preocupavam devidamente em dar respostas à "situação" dos seus interlocutores. Já a teologia apologética buscava contextualizar a mensagem cristã à mentalidade moderna sem, contudo, perder a sua palavra e singularidade.

Com o propósito de construir uma answering theology é que Tillich estudou os grandes filósofos. A filosofia põe as questões e espera que a teologia as responda. Sua Teologia Sistemática foi constituída segundo o ritmo de perguntas e respostas que emergem da situação existencial. Braaten comenta a importância dessa relação ao afirmar "que a filosofia levanta a questão que a teologia deve responder", isto é, "o evangelho é a resposta divina às questões da existência humana vivida sob a lei. A filosofia funciona analogicamente à lei como a teologia ao evangelho" (BRAATEN, 2004, p.13). A filosofia é essencial na tarefa apologética da teologia. Tillich tinha a mais alta consideração por ela: "Nenhum teólogo deve ser levado a sério como teólogo, mesmo que seja um grande cristão e um grande estudioso, se sua obra mostrar que ele não leva a sério a filosofia" (TILLICH, 1955, p.7,8).

\subsection{Opção por espaços fronteiriços}

A palavra "fronteira" tem um campo semântico interessante. Do sentido literal de limitação de área ao sentido figurado como contorno de espaços imaginários, o termo sugere a consciência de pelo menos dois

Palavra de difícil tradução no pensamento de Paul Tillich. O termo "situation" aparece entre aspas em sua Teologia Sistemática e parece indicar o âmbito existencial ou o lugar existencial. Talvez a expressão em alemão "Sitz in leben" traduza bem a opção de Tillich pela palavra "situation". 
ambientes separados e/ou ligados por uma linha fronteiriça. O escritor, biólogo e jornalista moçambiquenho Mia Couto, no texto Repensar o pensamento, redesenhando fronteiras, ilustra a imagem física e abstrata suscitada pelo signo "fronteira" e o desafio para o pensamento:

Nosso pensamento, como toda a entidade viva, nasce para se vestir de fronteiras. Essa invenção é uma espécie de vício de arquitetura: não há infinito sem linha do horizonte. Desde a mais pequena célula aos organismos maiores, o desenho de toda a criatura pede uma capa, um invólucro separador. A verdade é esta: a vida tem fome de fronteiras. É assim que se passa e não haveria nada a lamentar. Porque essas fronteiras da natureza não servem apenas para fechar. Todas as membranas orgânicas são entidades vivas e permeáveis. São fronteiras feitas para, ao mesmo tempo, delimitar e negociar. O "dentro" e o "fora" trocam-se por turnos (COUTO, 2014). ${ }^{8}$

A fronteira é cheia de oportunidades e rica em novas possibilidades e desafios. $\mathrm{O}$ espaço fronteiriço desinstala o sujeito da zona de conforto e o provoca a mudança. Na fronteira, a ordem dá lugar à desordem e o simples cede espaço ao complexo. Segundo Couto:

Precisamos de modelos para entender um universo (que é, afinal, um pluriverso ou um multiverso) e que foi construído em permanente mudança, no meio do caos e do imprevisível. Esses modelos simplificam o que só pode ser entendido como entidade complexa e complicam o que só em simplicidade pode ser apreendido (Ibidem).

As palavras de Couto testificam a intuição de Paul Tillich de que a fronteira é o melhor lugar para romper com a inércia, o medo do diferente, e adentrar novos conhecimentos, novas experiências, uma visão mais ampla do mundo e do humano.

No pensamento tillichiano, a "fronteira" (boundary) é chave hermenêutica de sua vida e teologia, a saber, a reivindicação do espaço fronteiriço entre diferentes saberes e possibilidades. Estar neste espaço consiste em estar numa posição frutífera para o pensamento. $\mathrm{Na}$ autobografia On the Boundary, Tillich deixa transparecer o lugar privilegiado

8 COUTO, Mia. Repensar o pensamento, redesenhando fronteiras. Disponível em: $<\mathrm{http} / / /$ fronteiras.com/canalfronteiras/entrevistas/?16,176>. Acesso em 7 de dez. 2014. 
da situação de fronteira na aquisição do conhecimento: "A fronteira é o melhor lugar para a aquisição de conhecimento" (TILLICH, 1966, p.13).

Uma situação de fronteira se dá quando a possibilidade humana alcança seu limite, quando a existência humana é confrontada pela ameaça última. Segundo o próprio Tillich:

A existência na fronteira, em uma situação de limite, é cheia de tensão e movimento. Não é estática, mas, ao contrário, é uma travessia e retorno, uma repetição de retorno e travessia, um vai-e-vem, cujo objetivo é criar uma terceira área além dos limites territoriais, uma área onde se pode permanecer por um tempo sem ser encerrado em algo hermeticamente limitado (TILLICH, 1966, p.53).

No âmbito da ciência, "fronteira" dá a ideia da totalidade dos espaços existentes nas linhas fronteiriças entre os saberes. Conforme Homi Bhabha, as regiões fronteiriças são ideais para a construção de identidades porque favorecem a articulação de diferenças culturais num movimento de deslocamento e sobreposição de diferenças. Segundo ele, “esses 'entre-lugares' fornecem o terreno para a elaboração de estratégias de subjetivação - singular ou coletiva - que dão início a novos signos de identidade e postos inovadores de colaboração e contestação" (BHABHA, 2013, p.20).

A fronteira é ambiente de mobilidade, andança, no qual se permitem encontros com "o novo e o diferente". Não há espaço na fronteira para diálogos relativos e/ou absolutos. $\mathrm{O}$ ambiente fronteiriço é lugar de diálogo relacional, para uma vivência aberta à interação entre os dialogantes, possibilitando assim o deslocamento dos seus próprios lugares enunciativos para um "terceiro espaço" em que emerge a novidade. A fronteira é espaço de abertura e criatividade.

O lugar de fronteira é propício para refletir a partir do horizonte da fé, instituído em conteúdos objetivos no seio da confessionalidade religiosa, advém boa parte da matéria-prima para a reflexão teológica e do horizonte comum da razão lógica e investigativa, instituída em métodos e teorias, advêm as regras do jogo do conhecimento, tanto quanto em outras áreas. Portanto, as margens são espaços de criação, de colaboração e de contestação, em que o sujeito peregrina numa experiência de travessia e retorno com os companheiros dos outros lugares, criando-se um terceiro espaço vivencial capaz de recriações. 
É exatamente no espaço limítrofe que Paul Tillich elabora sua vida e sua obra, uma vez que ele mesmo escreve sua autobiografia a partir das fronteiras que o fizeram. A importância desta imagem está para além das tensões que ela sugere, e remete à experiência que ela traz consigo, de encontro e de diálogo. Tillich constantemente usa a palavra "encontro" (encounter) em seus textos, sugerindo a riqueza para o pensamento de se experimentar algo, sobretudo, novo.

A riqueza da teologia de Tillich comporta uma intenção comunicativa própria de alguém que tanto experimentou fronteiras. Sua reflexão teológica permitiu "suportar e transcender suas fronteiras pessoais e intelectuais, transgredindo-as enquanto situação de limite para as tornar lugar de começos e novas possibilidades" (MUELLER, BEIMS, 2005, p.121). Tillich não soube só reconhecer e relativizar fronteiras, mas soube conciliar os territórios por elas delimitados. Aí está a riqueza e a criatividade do seu método da correlação.

O método da correlação tillichiano tem como lócus a situação de fronteira (boundary-situation), que busca explicar os conteúdos da fé através de perguntas e respostas teológicas em interdependência mútua. O próprio termo "correlação" já comporta em si mais de uma possibilidade, abrindo caminhos para expressar a relação entre conceitos, ideias e pensamentos que podem ser totalmente diferentes.

Pensar a teologia, especificamente no âmbito teórico-teológico, a partir do conceito de "fronteira" de Paul Tillich é colocá-la em um espaço propício para que ela, ao mesmo tempo, acolha a inquietação do lugar e manifeste a sua própria palavra, quer dizer, a epistemologia da teologia é interpelada pela estrutura teórica de outros conhecimentos a dizer o que lhe é próprio.

A teologia de fronteira de Tillich evidencia-se, sobretudo, na relação que ele institui entre religião e cultura secular, mediado pelo método de correlação, segundo o qual o conteúdo da Revelação cristã se apresenta e demonstra como resposta às interpelações que emergem da existência do ser humano diante dos desafios dos tempos modernos. O caminho proposto por Tillich faz da fronteira o lugar ideal para que haja intercâmbio entre as situações concretas da vida e a perspectiva da fé. Portanto, aclarar o modo como a correlação é utilizada é fundamental para a teologia tillichiana. 


\subsection{O método da correlação}

O caminho (método) da correlação perpassa a vida e a teologia de Paul Tillich. Embora não seja o único, ele deu grande destaque a correlação em seu fazer teológico apologético e em sua principal obra: Teologia Sistemática.

O método da correlação surge a partir da insatisfação de Tillich diante de propostas teológicas que não dão conta de "responder" aos questionamentos das sociedades modernas. Ele criticava sistemas teológicos que ou sacrificavam o conteúdo da Revelação ou não levavam em conta a situação dos seus interlocutores. Para ele, a correlação entre Revelação e "situação" é fundamental: "não são muitos os sistemas teológicos que souberam combinar perfeitamente essas duas exigências. A maioria deles ou sacrificam elementos da verdade ou não são capazes de falar no momento atual" (TILLICH, 2005, p.22).

O método da correlação não é uma novidade de Tillich. A contribuição tillichiana consiste em fazer da correlação o ângulo de observação preferido. Mondim afirma que:

O princípio da correlação não foi inventado por Tillich. Já podia ser encontrado em Platão, Aristóteles e Tomás de Aquino [...] Mas no sistema tillichiano o princípio da correlação adquire um alcance que nunca alcançara em nenhum outro filósofo e teólogo. Toda a realidade, todas as dimensões do ser, todas as formas de agir, todas as questões filosóficas e teológicas são exploradas e resolvidas através desse princípio. No sistema de Tillich, o princípio da correlação exerce o papel exercido pelas Ideias no sistema de Platão, pelo Ato e Potência no sistema de Aristóteles, pelo Ser-Perfeição-Absoluto no sistema de Tomás de Aquino, pela Substância no sistema de Spinoza, pelos Juízos Sintéticos a priori no sistema de Kant: isto é, representa o princípio hermenêutico supremo, o cânon interpretativo fundamental, o ângulo de observação preferido, o refletor potente que ilumina todo o palco do mundo (MONDIM, 2003, p.98).

Para Tillich, a realidade é um entrelaçamento de correlações e, dentre elas, há uma que tem prioridade absoluta sobre todas as outras: é a correlação que intersecciona a realidade verticalmente, de baixo para cima (e vice-versa), do ser humano para Deus (e vice-versa). É com base nessa correlação que edifica a sua Teologia Sistemática articulada em "cinco partes, justamente porque cinco são as ramificações funda- 
mentais da correlação vertical: razão-Revelação, ser-Deus, vida-Espírito, homem-Cristo, história-Reino de Deus" (MONDIM, 2003, p.98).

O método é fundamental ao princípio de racionalidade metodológica. "É um instrumento, literalmente um 'caminho em torno de', que deve ser adequado a seu assunto" (TILLICH, 2005, p.74). Ele se mostra adequado à medida que desenvolve o próprio processo cognitivo de maneira que para cada assunto há um método específico. Não se espera que um único método aborde tudo. Há variações metodológicas. Segundo Tillich:

Nenhum método pode reinvidicar ser adequado para todo e qualquer assunto. O imperialismo metodológico é tão perigoso quanto o imperialismo político. Como esse último, ele se desfaz quando os elementos independentes da realidade se revoltam contra ele. Um método não é uma "rede indiferente" com que se prende a realidade, mas um elemento da própria realidade (TILLICH, 2005, p.74).

Mesmo assumindo o princípio da correlação como caminho para perguntas e respostas, Tillich mostra lucidez ao dizer que:

O método de correlação não está a salvo de distorções; nenhum método teológico está [...] Nenhum método constitui uma garantia contra esses equívocos (condicionamentos entre perguntas e respostas). Como todo empreendimento da mente humana, a teologia é ambígua. Mas essa ambiguidade não é argumento contra a teologia ou contra o método de correlação. Como método, a correlação é tão antiga quanto a própria teologia. Consequentemente, não inventamos um método novo, mas tentamos explicitar as implicações de métodos antigos, a saber, o da teologia apologética (Idem, p.311).

O adjetivo "correlação" atrelado ao substantivo "método", no pensamento de Tillich, pode ser usado de três maneiras: apontando a correspondência de diferentes séries de dados, como em registros estatísticos, designando a interdependência lógica de conceitos, como em relações polares, e pode designar a interdependência real de coisas ou eventos em conjuntos estruturais (Idem, p.75). O seu emprego no âmbito teológico engloba os três sentidos de modo que: 
Há uma correlação no sentido de correspondência entre símbolos religiosos e aquilo que é simbolizado por eles. Há uma correlação no sentido lógico entre conceitos que denotam o humano e aqueles que denotam o divino. E há uma correlação no sentido fatual entre a preocupação última do ser humano e aquilo pelo que ele se preocupa de forma última. O primeiro sentido de correlação se refere ao problema central do conhecimento religioso. O segundo sentido de correlação determina as afirmações sobre Deus e o mundo. O terceiro sentido de correlação qualifica a relação divino-humana dentro da experiência religiosa (Ibidem).

Ao usar o método de correlação, a teologia "faz uma análise da situação humana a partir da qual surgem as perguntas existenciais e demonstra que os símbolos usados na mensagem cristã são as respostas a estas perguntas" (Idem, p.76). As respostas implícitas no evento da Revelação passam a ser significativas na medida em que estejam em correlação com questões que dizem respeito à totalidade de nossa existência. "Só as pessoas que experimentaram o choque de transitoriedade, a angústia na qual se tornam conscientes de sua finitude, a ameaça do não-ser, podem entender o que significa a palavra de Deus", afirma Tillich (Ibidem).

\subsection{A praticidade do método}

A preocupação última do ser humano é aquilo que determina o "ser" ou o "não-ser". Segundo Tillich, o termo "ser" "significa a totalidade da realidade humana, a estrutura, o sentido e a finalidade da existência" (TILLICH, 2005, p. 31). O “não ser" seria então o contrário, isto é, o estado de fragmentação do ser, a negação, a sua alienação no tocante à finalidade da sua existência. Só são teológicas aquelas afirmações que tratam de seu objeto na medida em que este possa se tornar para o ser humano uma questão de ser e não-ser.

Se o teólogo abandona a dimensão da experiência da atitude existencial, como o fizeram alguns teólogos "empíricos", será conduzido a uma fala desconectada da realidade e não será "reconhecida por ninguém que não participe das pressuposições existenciais do teólogo pretensamente empírico. A teologia é necessariamente existencial, e nenhuma teologia pode escapar do círculo teológico" (Idem, p.40). Somente a participação em todas as formas culturais que expressam a interpretação da existência por parte do ser humano moderno pode dar 
à teologia a condição de "apologética" em direção à Revelação. Nas palavras de Tillich:

A teologia apologética deve mostrar que tendências imanentes a todas as religiões e culturas caminham em direção à resposta cristã. E isto se refere tanto às doutrinas quanto à interpretação teológica da teologia [...] Considerada no sentido mais amplo da palavra, a teologia, o logos ou o raciocinar sobre o Theos (Deus e as coisas divinas), é tão antiga como a própria religião (Idem, p.32).

O método da correlação dá ao teólogo a condição de participar do círculo teológico, isto é, coloca-o, que é determinado por sua fé, em condições de participação, ouvir e responder, da existência humana com uma palavra de Deus às mazelas que envolvem o mundo e o humano. Para que este círculo seja efetivo, não só é necessário o envolvimento na situação existencial, mas o teólogo precisa rever o sentido e o alcance da mensagem cristã para que esta realmente tenha o que dizer à contemporaneidade.

Tillich, como acadêmico, não é ingênuo e reconhece os limites do método da correlação. Na introdução ao segundo volume da Teologia Sistemática, ele esclarece aos seus críticos o modo como utiliza o termo "correlação" e assinala os problemas relacionados à independência e à interdependência das perguntas existenciais e das respostas teológicas. "A resposta pode condicionar a pergunta a ponto de se perder a seriedade da situação existencial. Ou a pergunta pode condicionar a resposta a ponto se perder o caráter revelatório da resposta", afirma ele (Idem, p.311).

Para resolver os problemas de condicionamento entre perguntas e respostas, Tillich faz alusão à importância de situar a discussão dentro do "círculo teológico", ou seja:

O teólogo enquanto teólogo está comprometido com uma expressão concreta da preocupação última, ou seja, falando religiosamente, com uma experiência revelatória. À base desta experiência concreta, o teólogo traz suas reivindicações universais, como o fez o cristianismo com a afirmação de que Jesus como o Cristo é o Logos. Podemos entender esse círculo como uma elipse (não como um círculo geométrico) cujos dois pontos centrais são constituídos pela pergunta existencial e pela resposta teológica. Ambos estão dentro da esfera do compromisso religioso, mas não 
são idênticos. O material da pergunta existencial é tomado da totalidade da experiência humana e de suas múltiplas formas de expressão [...] $\mathrm{O}$ teólogo não fica parado na resposta teológica que anuncia. Ele só pode dar essa resposta de forma convincente se participa com todo seu ser na situação da pergunta, a saber, na condição humana (Idem, p.310).

No esforço deste empreendimento, Tillich demonstra a sua abertura teológica quando situa os lugares da Bíblia, da Igreja, da Tradição e da experiência subjetiva dentro da dinâmica da correlação entre a situação e a fé cristã. Não pretendemos alargar o conceito que ele dá à Bíblia, à Igreja e à Tradição. A ideia aqui é mostrar como ele lida com estes elementos e sua importância no diálogo com a cultura. Para ele, a "Bíblia é a fonte básica da teologia sistemática, porque é o documento original sobre os eventos em que a igreja cristã se fundamenta" (Idem, p.50).

Tillich rejeita o biblicismo neo-ortodoxo, que vê a Bíblia como única fonte da Palavra de Deus. Dentre os vários sentidos diferentes que ele dá ao termo "Palavra" estão todos unidos em um só: "Deus manifesto, isto é, manifesto em si mesmo, na criação, na história da Revelação, na Revelação final, na Bíblia, nas palavras da Igreja e de seus membros" (Idem, p.169). Este é o significado do símbolo a "Palavra de Deus". Tillich pensa que:

A "Palavra de Deus" não está limitada às palavras de um livro e que o ato da Revelação não se identifica com a "inspiração" de um "livro de revelações", mesmo que o livro seja o documento da "Palavra de Deus" final, plenitude e critério de todas as revelações. A mensagem bíblica abrange mais (e menos) do que os livros bíblicos. A teologia sistemática, portanto, tem fontes adicionais, além da Bíblia. [...] A Bíblia, contudo, é a fonte básica da teologia sistemática, porque é o documento original sobre os eventos em que a igreja cristã se fundamenta (Idem, p.50).

Tillich assume uma exegese que ao mesmo tempo é histórica, por entender que a Bíblia não apresenta fatos puros, e crítica, ao submeter o texto bíblico aos instrumentos da reflexão crítica moderna. Mas alerta para o fato de que a relevância do método histórico-crítico se faz na parceria interpretativo-existencial. Diz ele:

O teólogo bíblico, na medida em que é teólogo, não nos apresenta fatos puros. Ele nos oferece fatos teologicamente interpretados. Sua exegese 
é pneumática (espiritual) ou, como a chamaríamos hoje, "existencial" [...] A teologia sistemática necessita de uma teologia bíblica que seja histórico-crítica sem quaisquer restrições, mas que seja, ao mesmo tempo, interpretativo-existencial, levando em conta o fato de que ela trata de assuntos de preocupação última (Idem, p.51).

Ao contrário de algumas tradições protestantes radicais, Tillich não abandona a Tradição no exercício da leitura bíblica ou da teologia. Segundo ele:

A atitude biblicista radical é uma auto-ilusão. Ninguém é capaz de saltar sobre dois mil anos de história da igreja e tornar-se contemporâneo dos escritores do Novo Testamento, exceto no sentido espiritual de aceitar Jesus como o Cristo. Toda pessoa que se defronta com um texto bíblico é guiada, em sua compreensão religiosa do mesmo, pela compreensão de todas as gerações anteriores. Até mesmo os reformadores eram dependentes da tradição romana contra a qual protestaram [...] Não se pode negar a história da igreja. Por conseguinte, é uma necessidade tanto religiosa quanto acadêmica afirmar franca e decisivamente a relação da teologia sistemática com a tradição eclesiástica (Idem, p.52).

O que ele faz é retirar a teologia do domínio dos diversos tipos de magistério eclesiástico. A teologia não se limita a uma instituição específica - a Igreja. Mesmo reconhecendo a importância da confissão de fé, a Revelação e a teologia podem ser encontradas também fora da instituição que tradicionalmente as diz controlar. Calvani aponta para as contribuições desta postura de Tillich:

Isso traz grandes implicações para a noção de Deus e sua Revelação. A partir de Tillich, a Revelação não está somente onde a Igreja diz estar. Está mais além, nos lugares onde geralmente a Igreja pouco se interessa em ir, nos cenários e figuras que a Igreja pouco se interessa em contemplar e nos sons que ela pouco se interessa ouvir. A teologia é libertada da tutela da Igreja e do consequente isolamento em que se encontrava, em parte devido às suas próprias restrições temáticas. Não significa que a teologia da Igreja seja desqualificada e condenada. Ela ainda tem uma função, mas é confinada aos limites do grupo religioso ao qual é chamada a servir (CALVANI, 2010, p.88-89).

Tillich concorda com a libertação da teologia de suas formas tradicionais. O seu pensamento favorece a possibilidade da teologia assumir 
formas diferentes na tentativa de dialogar com a cultura. Não é só a filosofia que coloca perguntas, a arte, as ciências, a economia, a política também colocam perguntas e o teólogo precisa estar atento às questões levantadas pelo contexto em que vive. Para que a teologia seja relevante aos tempos atuais, ela deve evitar o tradicionalismo que enrijece a estrutura e mortifica o discurso. Ela necessita ser aberta ao mundo que a cerca numa postura de diálogo repensando, quanto necessário, as categorias que as constituem. Calvani afirma que:

Não podemos nos esquecer que a teologia é uma manifestação cultural como as demais no que diz respeito à sua forma; a teologia cristã, no entanto, deve ter seu conteúdo essencial fundamentado na confissão de Jesus enquanto o Cristo, o portador do Novo Ser. Esse conteúdo, porém, pode - e deve - ser comunicado de diferentes formas, o que abre a possibilidade de libertar a teologia das formas arraigadas em que ela tem se constituído no decorrer da história; e considerar a viabilidade de responder às perguntas levantadas pela arte, por exemplo, através de uma teologia estética, tanto na forma como no conteúdo. Seria o caso da teologia em forma de poesia ou de música (Idem, p.91).

Tillich julga ser importante também, como fonte para a teologia, o rico material oferecido pela história da religião e da cultura como seus meios de expressão, "cita-as a fim de confirmar suas afirmações, luta contra elas como contradições da mensagem cristã e, sobretudo, formula as perguntas existenciais implícitas nelas e às quais sua teologia pretende responder" (Idem, p.54). Na pretensão de uma "teologia da cultura", o teólogo se lança na condição de discernir os estilos que permeiam as culturas. Segundo Tillich:

A chave para a compreensão teológica de uma criação cultural é seu estilo [...] O estilo de uma época se expressa em suas formas culturais, na escolha de objetos, nas atitudes de suas personalidades criativas, em suas instituições e costumes. "Ler estilos" é tanto uma arte quanto uma ciência. Requer-se uma intuição religiosa, com base em uma preocupação última, para penetrar nas profundidades de um estilo, para chegar ao nível em que uma preocupação última exerce seu poder condutor. Mas é isso que se exige do teólogo que se ocupa com a história da cultura. E, ao desempenhar essa função, ele abre uma fonte criativa para a teologia sistemática (TILLICH, 2005, p.55). 
Interessante também é o modo como Tillich se apoia no valor dado à experiência. Ela não é a fonte da qual procedem os conteúdos da teologia sistemática, mas o meio através do qual eles são existencialmente recebidos. Segundo ele:

A experiência é o meio através do qual as fontes "falam" a nós, através do qual podemos recebê-las [...] Nenhuma teologia atual deveria fugir de uma discussão do método experimental de Schleiermacher, seja para concordar ou discordar dele. Um dos motivos do efeito perturbador da teologia neo-ortodoxa foi que ela se distanciou completamente do método de Schleiermacher (Idem, p.56).

"As fontes da teologia só podem ser fontes para quem participa nelas", afirma ele (Idem, p.56). O princípio da experiência é o meio através do qual os conteúdos da teologia sistemática são existencialmente recebidos. O termo "experiência", segundo nosso autor, pode ser usado de três modos: ontológico, científico e místico. Em linhas gerais, podemos dizer que o sentido ontológico da experiência remete ao positivismo no qual a realidade é idêntica à experiência. O sentido científico dá ao termo experiência o status de momento da articulação de experimentação e verificação de determinado dado pesquisado. Já o sentido místico, ou experiência por participação, é o problema real da teologia experimental. É ela que dá sentido aos dois conceitos anteriores revelando a nossa preocupação última. "A experiência como presença inspiradora do Espírito seria a fonte última da teologia", conclui Tillich (Idem, p.60).

O mundo da experiência é uma fonte inesgotável para a teologia. É obrigação do teólogo participar ativamente dos questionamentos do mundo para que a sua teologia tenha o que dizer. Manter uma postura de abertura perante a experiência do mundo é fundamental. Segundo Tillich:

Estar aberto a novas experiências, que podem inclusive ultrapassar os limites da experiência cristã, é agora a atitude própria do teólogo. Ele não está confinado a um círculo cujo centro é o evento de Jesus como o Cristo. Sem dúvida, como teólogo, ele também atua em um círculo, mas em um círculo cuja periferia é dilatável e cujo centro é móvel. A "experiência aberta" seria a fonte da teologia sistemática (Ibidem). 
Vemos neste pequeno trecho da Teologia Sistemática de Tillich uma intuição relevante para a teologia pública na atualidade. A percepção da dupla cidadania do teólogo, cidadão da Igreja e do mundo, dá condições à teologia de se lançar nas coisas do mundo sem que para isso negue as coisas da Igreja. Aliás, sem identidade própria o teólogo se perderia no mundo plural. O enraizamento na confissão não só permite a identificação como possibilita abertura ao diálogo com o outro como parceiro na construção de um mundo melhor. Falaremos melhor sobre isto no próximo capítulo.

O teólogo, para dialogar com as culturas, não precisa abandonar a Igreja. Pelo contrário, Tillich diz que a Igreja é o lar do teólogo. É a partir da Igreja, nela enraizado, sem se levar pelo ostracismo, que as fontes e as normas da teologia têm existência real. Só neste lugar a experiência pode converter-se em meio da teologia. O teólogo sem senso de pertença perde o lugar de trabalho. A Igreja "é seu lugar mesmo que ele trabalhe e proteste contra ela. O protesto é uma forma de comunhão [...] Para ser uma norma genuína, não deve ser uma opinião privada do teólogo, mas a expressão de um encontro da Igreja com a mensagem cristã" (Idem, 63).

A norma da teologia preserva a substância, mas necessita de uma forma mais adequada à situação presente e à fonte bíblica. Necessário para uma answering theology a distinção entre substância visada e a formulação cultural de sua norma. Assim, Tillich propõe o "Novo Ser em Jesus como o Cristo" a norma material da teologia sistemática e a mais adequada para a presente situação apologética (Idem, p.64). "Novo Ser" é a resposta teológica à constatação da realidade de alienação da existência humana diante da falta de sentido e desespero em todos os setores da vida. Inspirado na categoria paulina da "nova criação" (2Co 5,17 ) com o seu "poder de superar as divisões demoníacas da "velha realidade' na alma, na sociedade e no universo" (Ibidem). Tillich vê a mensagem cristã no "Novo Ser" como resposta à pergunta implícita em qualquer situação humana. Como esta norma se relaciona com a Bíblia, a fonte básica? Tillich responde:

A Bíblia pode ser chamada de norma da teologia sistemática só porque a norma se deriva da Bíblia. Mas ela se deriva dela num encontro da igreja 
com a mensagem bíblica. A norma derivada da Bíblia é, ao mesmo tempo, o critério para o uso da Bíblia pela teologia sistemática. Na prática, esta foi sempre a atitude da teologia [...] A Bíblia como um todo nunca foi a norma da teologia sistemática. A norma tem sido um princípio derivado da Bíblia num encontro entre ela e a igreja (Idem, p.65).

Outra preocupação de Tillich é quanto à linguagem utilizada pelo teólogo na transmissão da mensagem cristã. Os polos da situação e da mensagem cristã no método da correlação são mediados pela linguagem. Se o objetivo é transmitir a Palavra de Deus de modo que as culturas compreendam o seu significado e relevância, a linguagem do teólogo não pode ser uma linguagem restrita à terminologia bíblica ou à linguagem da teologia clássica. Antes, ele deveria usar termos filosóficos e científicos quando necessários para sua tarefa de explicar os conteúdos da fé cristã observando a clareza semântica e a pureza existencial. Para Tillich, o teólogo deve "evitar a ambiguidade conceitual e uma possível distorção da mensagem cristã pela intromissão de ideias anticristãs numa roupagem terminológica filosófica, científica ou poética [...] A teologia depende de lógica formal tanto quanto qualquer outra ciência" (Idem, p.70).

A palavra da fé é determinada pela experiência da fé. É, pois desta que a teologia fontalmente se nutre. A raiz etimológica da palavra teologia tem um sentido místico. Ela está ligada àquilo que é contemplativo. Primeiro no panteão grego, depois no panteão romano, a teologia remete à contemplação e adoração dos deuses. Na tradição cristã ocidental, aos poucos a vertente mística do termo foi perdendo espaço para a intelecção da fé, correndo o risco de se perder no racionalismo teórico sobre as coisas de Deus e se esquecendo das pessoas de Deus. Trocaram a busca por Ele na relação com o outro por uma obsessão pela ideia sobre Ele. Nesta lógica, Deus deixou se ser alguém com quem nos relacionamos para ser um objeto de estudo. É nesse sentido que vai a crítica de Tillich quando a teologia é objetivada:

Alguns teólogos empíricos tentaram aplicar o método da experiência científica à teologia, mas não lograram êxito, e nem poderiam, por duas razões. Primeiro, o objeto da teologia (isto é, nossa preocupação última e suas expressões concretas) não é um objeto dentro da totalidade da experiência científica. Ele não pode ser descoberto por uma observação 
distanciada ou por conclusões derivadas de tal observação. Só pode ser encontrado em atos de entrega e participação. Segundo, ele não pode ser testado por métodos científicos de verificação. Nesses métodos, o sujeito verificador se mantém fora do processo de verificação. E se isso é parcialmente impossível, como, por exemplo, na microfísica, o cientista inclui os efeitos desta variante em seus cálculos (Idem, p.59).

O "objeto" da teologia passa pela verificação do sujeito que participa efetivamente do processo. É uma relação, mediada por um labor inconcluso e uma linguagem aproximativa, em que o sujeito (que percebe) e o objeto (o que é percebido) modificam um ao outro. O sujeito modifica o objeto, pois lhe atribui significado, e o objeto modifica o sujeito, pois altera a subjetividade humana. A teologia que daí emerge não se contenta com regras hermenêuticas rígidas (epistemologia) e nem pela busca pelo sentido do sentido (ontologia), mas o sentido para a sua práxis em uma operatividade social.

\section{Conclusão}

É fascinante a dinamicidade e a capacidade de abertura do pensamento de Tillich. Estar aberto a novas experiências, que podem inclusive ultrapassar os limites da experiência cristã, é atitude própria do teólogo que busca relevância para a sua teologia. Uma teologia que almeja dirigir sua palavra ao mundo, já não pode fazê-lo se limitando às referências da sua própria confissão. Vimos, segundo Tillich, que o teólogo não está confinado a um patrimônio simbólico rígido e imóvel. Aí não seria um "evento simbólico", mas "sinal”. Enquanto o sinal é apenas informativo, indica uma realidade estranha; o símbolo representa a realidade à qual remete, desvela-a e participa de seu poder. Os símbolos religiosos desvelam a dimensão profunda da realidade, e remetem a uma realidade que transcende toda realidade condicionada, tornando possível a experiência da dimensão da profundidade, a experiência do Incondicionado. Assim, o círculo teológico cujo centro é Jesus Cristo é dinâmico e aberto na acolhida de tudo aquilo que nos aproxima do Novo Ser tirando-nos da alienação existencial.

A teologia provinciana, fechada em si mesma, corre o riso de ficar à margem das grandes questões mundiais. $\mathrm{O}$ seu labor de gueto não permite que ela se coloque em condições de diálogo com as socieda- 
des plurais da contemporaneidade. O teólogo nesta condição não só se automarginaliza como também exclui todos que não se enquadram no seu ponto de vista. A visão de um ponto só passa a ser, para ele, a verdade absoluta. De fato, este teólogo não está à altura daquilo que seu trabalho exige dele. Mesmo que a teologia esteja enraizada na fé de uma religião, ela não se limita aí. Ele avança para além dos seus limites em busca de diálogos a favor de uma verdade que inclui.

A teologia de fronteira de Paul Tillich nos ajuda a perceber que a função da teologia não se restringe ao âmbito intraeclesial, pois a Igreja não existe para si mesma. Como o momento reflexo da experiência comunitária de fé, em perspectiva transformadora, a teologia vai para além das fronteiras eclesiais, para ser contributo da Igreja no mundo, em favor de toda a humanidade. Aqui legimita-se a vocação social do teólogo e a sua função profética.

\section{Bibliografia}

CALVANI, Carlos Eduardo. Teologia da arte: espiritualidade, igreja e cultura a partir de Paul Tillich. São Paulo: Ed. Fonte Editorial; Ed. Paulinas, 2010.

BHABHA, Homi. O local da cultura. 2.ed. Belo Horizonte: Ed. UFMG, 2013. GEFFRÉ, Claude. Crer e interpretar: a virada hermenêutica da teologia. Petrópolis: Vozes, 2004.

GRENZ, Stanley; OLSON, Roger. A teologia do século 20: Deus e o mundo numa era de transição. São Paulo: Ed. Cultura Cristã, 2003.

HAIGHT, Roger. Dinâmica da teologia. São Paulo: Paulinas, 2004.

MOLTMANN, Jürgen. Experiências de reflexão teológica: caminhos e formas da teologia cristã. São Leopoldo: Unisinos, 2004.

MONDIM, Battista. Os grandes teólogos do século vinte. São Paulo: Ed. Teológica, 2003.

MUELLER, Enio; BEIMS, Robert. Fronteiras e interfaces: o pensamento de Paul Tillich em perspectiva interdisciplinar. São Leopoldo: Ed. Sinodal, 2005.

Oxford Advanced Learner's Dictionary. 50.ed. Oxford University Press, 1998. TILLICH, Paul. Teologia da cultura. São Paulo: Fonte Editorial, 2009. . Teologia Sistemática. 5.ed. São Leopoldo: Ed. Sinodal, 2005. 1966. . The Future of the Religions. New York: Harper\& How Publishers, 
Perspectivas da teologia protestante nos séculos XIX e XX. São Paulo: ASTE, 2004.

. A Era Protestante. São Paulo: ASTE, 1996.

Biblical Religion and the Search for Ultimate Reality. Chicago: University of Chicago Press, 1955. 1966.

. The Future of the Religions. New York: Harper\& How Publishers,

TRACY, David. A imaginação analógica: a teologia cristã e a cultura do pluralismo. São Leopoldo: Unisino, 2004. 